\title{
Isolation and identification of angiotensin I-converting enzyme inhibitory peptides derived from thermolysin-injected beef M. longissimus
}

\author{
Juhui Choe', Kuk-Hwan Seol ${ }^{2}$, Hyun-Jin Kim³ , Jin-Taek Hwang ${ }^{4}$, Mooha Lee', and Cheorun Jo,5,*
}

\author{
* Corresponding Author: Cheorun Jo \\ Tel: +82-2-880-4820, Fax: +82-2-873-2271, \\ E-mail: cheorun@snu.ac.kr \\ 'Department of Agricultural Biotechnology, Center \\ for Food and Bioconvergence, and Research Institute \\ of Agriculture and Life Science, Seoul National \\ University, Seoul 08826, Korea \\ ${ }^{2}$ National Institute of Animal Science, Rural \\ Development Administration, Wanju 55365, Korea \\ ${ }^{3}$ Department of Food Science and Technology, \\ Gyeongsang National University, Jinju 52828, Korea \\ ${ }^{4}$ Korea Food Research Institute, Wanju 55365, Korea \\ ${ }^{5}$ Institute of Green Bio Science and Technology, Seoul \\ National University, Pyeongchang 25354, Korea
}

ORCID

Juhui Choe

https://orcid.org/0000-0003-4585-0327

Kuk-Hwan Seol

https://orcid.org/0000-0002-0907-882X

Hyun-Jin Kim

https://orcid.org/0000-0002-7284-3547

Jin-Taek Hwang

https://orcid.org/0000-0002-6650-7934

Mooha Lee

https://orcid.org/0000-0002-3487-9477

Cheorun Jo

https://orcid.org/0000-0003-2109-3798

Submitted Jun 15, 2018; Revised Aug 16, 2018; Accepted Aug 23, 2018
Objective: This study identified angiotensin I-converting enzyme (ACE) inhibitory peptides in beef $M$. longissimus injected with thermolysin $(80 \mathrm{ppm})$ and stored for 3 days at $5^{\circ} \mathrm{C}$. Methods: Crude peptides (molecular weight $<3 \mathrm{kDa}$ ) were obtained from the thermolysin hydrolysate and separated into seven fractions. Fraction V showing the highest ACE inhibitory activity was further fractionated, yielding subfractions V-15, V-m1, and V-m2, and selected for superior ACE inhibitory activity. Finally, twelve peptides were identified from the three peak fractions and the ACE inhibitory activity $\left(\mathrm{IC}_{50}\right)$ of each peptide was evaluated.

Results: The Leu-Ser-Trp, Phe-Gly-Tyr, and Tyr-Arg-Gln peptides exhibited the strongest ACE inhibitory activity ( $\mathrm{IC}_{50}$ values of $0.89,2.69$, and $3.09 \mathrm{mM}$, respectively) and had higher concentrations $(6.63,10.60$, and $29.91 \mathrm{pg} / \mathrm{g} ; \mathrm{p}<0.05)$ relative to the other peptides tested.

Conclusion: These results suggest that the thermolysin injection process is beneficial to the generation of bioactive peptides with strong ACE inhibitory activity.

Keywords: Beef; Injection; Thermolysin; Angiotensin I-converting Enzyme (ACE) Inhibitory Activity; Bioactive Peptides

\section{INTRODUCTION}

The renin-angiotensin system (RAS) is one of the most important humoral vasoconstrictor and vasodilator mechanisms involved in blood pressure regulation. The system starts with the conversion of angiotensinogen to a prehypertensive hormone, angiotensin-I (Asp-Arg-ValTyr-Ile-His-Pro-Phe-His-Leu), by the action of renin secreted by the kidney [1]. Angiotensin-I is further converted to the active form of the hormone angiotensin-II (Asp-Arg-Val-Tyr-Ile-HisPro-Phe), by the action of angiotensin-I converting enzyme (ACE). The $\mathrm{Zn}^{4+}$ metallopeptidase that removes the carboxy $(\mathrm{C})$-terminal dipeptide from decapeptide angiotensin I to generate the potent vasoconstrictor angiotensin II and inactivate the vasodilator bradykinin (ArgPro-Pro-Gly-Phe-Ser-Pro-Phe-Arg) or encephalitis [2]. The RAS can be regulated by ACE inhibitors [3].

Usually, ACE inhibitors are isolated naturally in mammals within the gastrointestinal tract during the normal metabolism of proteins [4]. However, a limited number of peptides can be released due to the specific cleavage sites of endogenous proteases that often display low productivity. For these reasons, the exogenous enzymatic hydrolysates from muscle protein have been used for the generation of ACE inhibitory peptides [5-7]. Porcine skeletal muscle proteins are hydrolyzed by eight proteases-thermolysin, proteinase $\mathrm{K}$, proteinase $\mathrm{E}$, ficin, papain, trypsin, $a$-chymotrypsin, and pepsin - and the ACE inhibitory activities of the hydrolysates have been measured [5]. Among the digests of the water-insoluble protein fraction 
prepared from muscle, a thermolysin digest demonstrated the highest activity among those that were tested. However, the majority of studies have been at the laboratory scale under optimum conditions, such as the use of high temperatures and ground meat.

The brine injection or marination process is commercially used for the quality enhancement of fresh meat [8]. Various ingredients including salt and synthetic or natural additives have been incorporated into brine, such as phosphate, fruit, or plant extracts containing proteases. A number of studies have reported that the injection process led to an instrumental or organoleptic enhancement of tenderness, juiciness, and the flavor of the meat $[9,10]$. A potent ACE inhibitory activity of sarcoplasmic and myofibrillar proteins extracted from beef injected with thermolysin and protease type XIII has been identified [11]. However, to our knowledge, there is little research on whole muscle injected with a proteolytic enzyme that could be utilized as a routine meat preparation practice in the home or in restaurants. Therefore, the aim of this study was to isolate and identify ACE inhibitory peptides from the hydrolysate of $M$. longissimus from beef generated by the injection of thermolysin followed by aging for 3 days at $5^{\circ} \mathrm{C}$ and to evaluate the ACE inhibitory activity of the identified peptides.

\section{MATERIALS AND METHODS}

\section{Reagents}

Thermolysin (T7902, Sigma, St. Louis, MO, USA), ACE (from rabbit lung), hippuryl-L-histidyl-L-leucine (HHL), hydrindantin, and lithium hydroxide were purchased from Sigma (USA). Acetonitrile (LC-MS grade) was purchased from Roth $\mathrm{GmbH}$ (Karlsruhe, Germany); L-Leucine from Aldrich Co. (Milwaukee, WI, USA); dimethyl sulfoxide (DMSO) from Merck (Darmstadt, Germany); ninhydrin from Riedel-de Haen (Seelze, Germany); and acetic acid and sodium hydroxide from Hayashi Pure Chemical Ltd. (Osaka, Japan).

\section{Meat sample preparation}

At $24 \mathrm{~h}$ postmortem, loins (M. longissimus) were obtained from Hanwoo steer (quality grade $1, \mathrm{n}=3$ ) slaughtered at a commercial slaughterhouse. The beef loins (200 g) were injected with $80 \mathrm{ppm}$ of thermolysin and stored for 3 days at $5^{\circ} \mathrm{C}$ for enzymatic proteolysis of the muscle proteins. The use of thermolysin and its concentration were determined based on our preliminary study. The process for isolation and identification of ACE inhibitory was presented in Figure 1.

\section{Extraction and ultrafiltration}

The peptides were extracted from the prepared beef samples as described in Jang and Lee [12]. Briefly, $5 \mathrm{~g}$ of each injected loin was homogenized in $20 \mathrm{~mL}$ of distilled water and boiled in a water bath at $95^{\circ} \mathrm{C}$ for $15 \mathrm{~min}$ to denature the enzymes.
The homogenate was filtered and centrifuged at $10,000 \times g$ for $20 \mathrm{~min}$ at $4^{\circ} \mathrm{C}$. The supernatant was collected and submitted to ultrafiltration at $4^{\circ} \mathrm{C}$ using a PM-10 membrane $(10,000$ molecular weight cut off [MWCO]; Amicon Co., Beverly, MA, USA) to remove high molecular weight peptides. The filtrates were then centrifuged at $4,000 \mathrm{~g}$ or $45 \mathrm{~min}$ at $4^{\circ} \mathrm{C}$ using an Ultracel 3K membrane (MWCO, 3,000; Amicon Co., USA). Prior to use, the membrane was activated with $10 \mathrm{~mL}$ of distilled water, and the remaining liquid was carefully removed. Separated crude peptide extracts were subsequently lyophilized and stored at $-80^{\circ} \mathrm{C}$ until required for ACE inhibitory activity analysis and further separation.

\section{Gel filtration}

The lyophilized crude peptides were dissolved in distilled water and again filtered through a Millipore membrane filter $(0.45$ $\mu \mathrm{m})$ and applied to a column $(\Phi 25 \times 1,200 \mathrm{~mm}$; Amersham Pharmacia Biotech, Little Chalfont, UK) saturated in P-2 resin. The eluent was deionized with distilled water with a flow rate of $0.8 \mathrm{~mL} / \mathrm{min}$. The fractions were collected at $15 \mathrm{~min}$ intervals with a fraction collector (Amersham Pharmacia Biotech, Uppsala, Sweden) and all fractions were subjected to absorbance measurements at $220 \mathrm{~nm}$ to confirm the peptide concentration. The fractions were collected on the basis of molecular weight and subsequently lyophilized prior to the ACE inhibitory activity measurements.

\section{Reversed-phase high-performance liquid chromatography}

The highest ACE inhibitory fraction selected after gel filtration was dissolved in water containing $1 \%$ trifluoroacetic acid (TFA). For the quantitative analysis of ACE inhibitory peptides, reversed-phase high-performance liquid chromatography (RP-HPLC) was performed with a Jasco PU-980 gradient system with a Jasco photodiode array (PDA) detector at $220 \mathrm{~nm}$ (Jasco, Tokyo, Japan). The fraction solution $(20 \mu \mathrm{L})$ was applied to a Vydac $\mathrm{C} 18$ reverse-phase column $(4.5 \times 25 \mathrm{~cm} ; 5 \AA$, $300 \mu \mathrm{m}$ pore size) and a solution containing $0.5 \%$ TFA, $0.5 \%$ acetonitrile (ACN), and $0.1 \%$ TFA was used for mobile phase at a flow rate of $1.0 \mathrm{~mL} / \mathrm{min}$. The seven major fractions were collected and subsequently lyophilized and the ACE inhibitory activity and concentration were measured. Among the seven fractions, the three fractions displaying strong ACE inhibition were applied to an ultra-performance liquid chromatography/quadrupole time-of-flight mass spectrometry (UPLC-QTOF-MS/MS) system to analyze the amino acid sequence of the peptides in the fractions.

\section{Small molecular peptide profiling by ultra performance liquid chromatography} An UPLC system (Waters, Milford, MA, USA) equipped with a binary solvent delivery system, an autosampler, and a PDA 


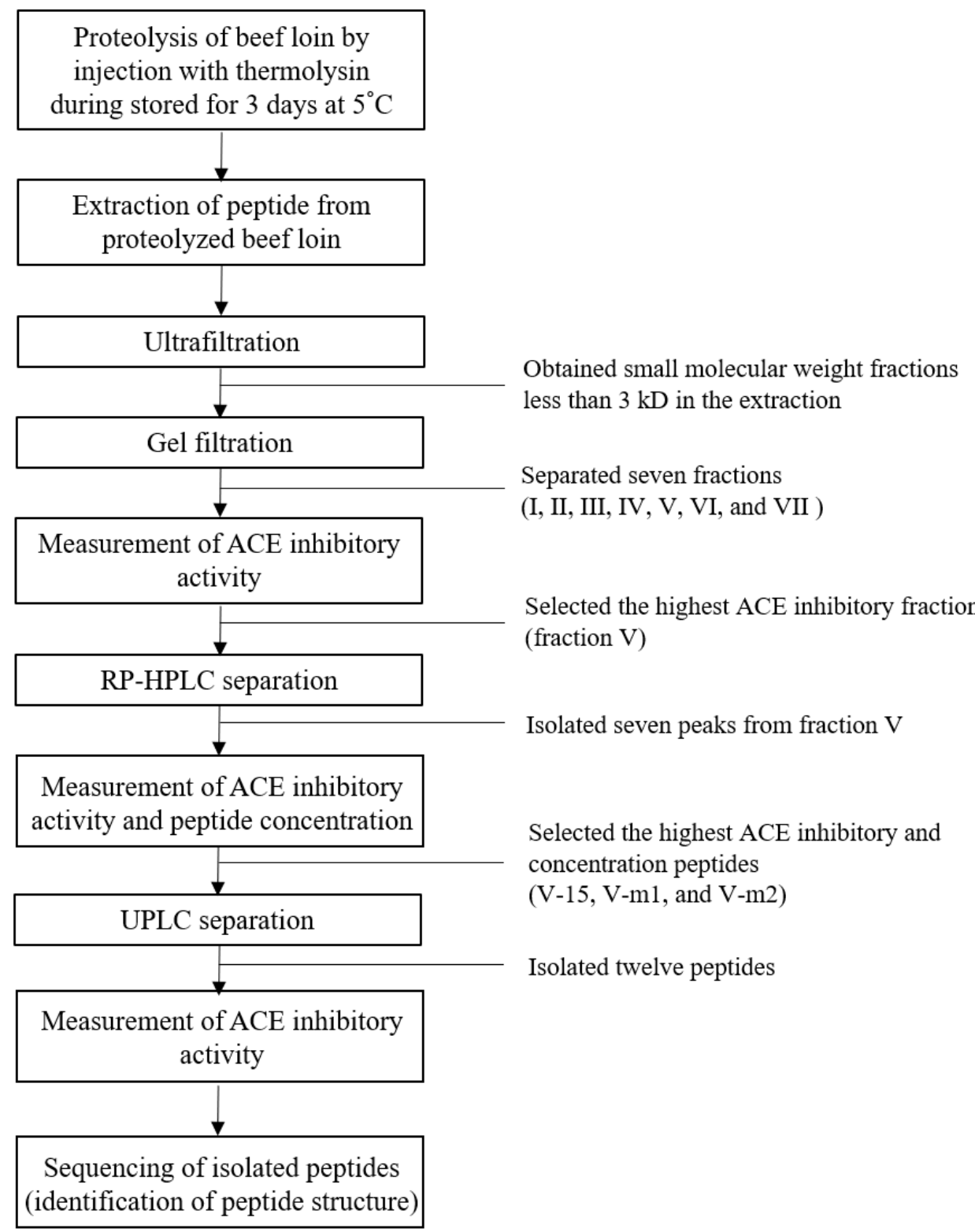

Figure 1. Flow chart for isolation and identification of angiotensin l-converting enzyme (ACE) inhibitory peptides.

detector was used to analyze the peptides. An Acquity UPLC BEH C18 column $(2.1 \times 100 \mathrm{~mm}, 1.7 \mu \mathrm{m}$; Waters, USA $)$ was equilibrated with water containing $0.1 \%$ TFA. HPLC fractions $(5 \mu \mathrm{L})$ were injected into the column and eluted with an ACN gradient containing $0.1 \%$ TFA at a flow rate of $0.35 \mathrm{~mL} / \mathrm{min}$ for $12 \mathrm{~min}$. The absorbance of the eluent was detected at 214 $\mathrm{nm}$ by the PDA detector and QTOF-MS/MS.

\section{UPLC-QTOF-MS/MS peptide sequence analysis}

The peptides from thermolysin hydrolysates of beef loin were separated and analyzed by UPLC-QTOF-MS/MS using a reverse phase $\mathrm{C} 18$ column (Waters, USA). The Q-TOF-MS/MS (Waters, USA) was operated in ESI positive mode. The capillary and sampling cone voltages were set at $2.78 \mathrm{kV}$ and $26 \mathrm{~V}$ respectively. The desolvation flow was set to $700 \mathrm{~L} / \mathrm{h}$ at a temperature of $300^{\circ} \mathrm{C}$ and the source temperature was set at $100^{\circ} \mathrm{C}$. The QTOF MS data was collected in a 50 to $1,000 \mathrm{~m} / \mathrm{z}$ range with a scan time of $0.2 \mathrm{~s}$ and an interscan delay time of $0.02 \mathrm{~s}$. The MS/MS spectra of the peptides were obtained using a collision energy ramp from 10 to $45 \mathrm{eV}$. The accurate mass and composition of the precursor ions and fragment ions were calculated and sequenced using MassLynx software (Waters, USA) and the peptides were analyzed and sequenced by a BioLynx peptide sequencer (Waters, USA).

\section{Angiotensin I-converting enzyme inhibitory activity} ACE inhibitory activity determination was achieved using the spectrophotometric method described by Cushman and 
Cheung [13]. For each assay, $100 \mu \mathrm{L}$ of HHL (12.5 mM in $0.05 \mathrm{M}$ sodium borate buffer) was incubated at $37^{\circ} \mathrm{C}$ for $5 \mathrm{~min}$. After incubation, $50 \mu \mathrm{L}$ of bovine peptide extracts and $150 \mu \mathrm{L}$ of ACE (peptidyldipeptide hydrolase from rabbit lung acetone extract) were added and the mixture incubated for $1 \mathrm{~h}$. The enzymatic reaction was stopped by adding $250 \mu \mathrm{L}$ of $0.5 \mathrm{~N}$ $\mathrm{HCl}$. The hippuric acid generated by the action of the angiotensin-converting enzyme on HHL was extracted from the acidified solution into $1 \mathrm{~mL}$ ethyl acetate by vortex mixing for $15 \mathrm{~s}$. This was centrifuged at $3,290 \times g$ for $10 \mathrm{~min}$ at $4^{\circ} \mathrm{C}$, and a $0.7 \mathrm{~mL}$ aliquot of each ethyl acetate layer was transferred to clean tubes and evaporated by heating at $95^{\circ} \mathrm{C}$ for $20 \mathrm{~min}$ in a water bath. The hippuric acid was redissolved in $3 \mathrm{~mL}$ of $1 \mathrm{M}$ $\mathrm{NaCl}$, and the amount formed was determined by absorbance at $228 \mathrm{~nm}$. The $\mathrm{IC}_{50}$ value, defined as the concentration of a peptide that inhibits $50 \%$ of the ACE activity, was determined by measuring the ACE inhibitory activity and the peptide contents of each of the extracts after regression analysis. ACE inhibitory activity (\%) was determined using the equation:

$$
\text { ACE inhibitory activity }(\%)=[1-(\mathrm{S}-\mathrm{SC}) /(\mathrm{B}-\mathrm{BC})] \times 100
$$

where $S$ and $B$ are optical density $(\mathrm{OD})$ values for the sample and blank, respectively, and $\mathrm{SC}$ and $\mathrm{BC}$ are the OD values for the sample control and blank, respectively.

\section{Chemical synthesis of peptides}

The identified peptides were chemically synthesized by Peptron
Ltd. (Daejeon, Korea) using the PenptrEX automatic peptide synthesizer and lyophilized for further confirmation of ACE inhibitory activity.

\section{Statistical analysis}

The entire experiments were replicated three times individually and all the samples were analyzed in duplicate. All data were expressed as means \pm standard deviation. One-way analysis of variance was carried out to analyze the data using SAS program (SAS Institute, Cary, NC, USA). The treatment (fraction or peptide type) was the fixed effect in the model. Comparison of mean values was performed to find out the effect of treatment using Duncan's multiple range tests. A value of $\mathrm{p}<0.05$ was considered significant differences.

\section{RESULTS AND DISCUSSION}

\section{Selection and isolation of angiotensin I-converting enzyme inhibitory peptides}

The thermolysin hydrolysates were filtered ( $\mathrm{MW}<3 \mathrm{kDa}$ ) by ultrafiltration using PM-10 and Ultracel $3 \mathrm{~K}$ membranes. After gel filtration, seven fractions were separated from the extract derived from beefloins injected with thermolysin and the ACE inhibitory activity of each fraction was evaluated at a concentration of $1 \mathrm{mg} / \mathrm{mL}$. Fraction V inhibited ACE activity at the highest rate (66.5\%), and the other five fractions (I, II, III, IV, and VI) achieved $50 \%$ inhibitory activity at a concentration of $1 \mathrm{mg} / \mathrm{mL}$ (Figure 2). This result corresponds with the results

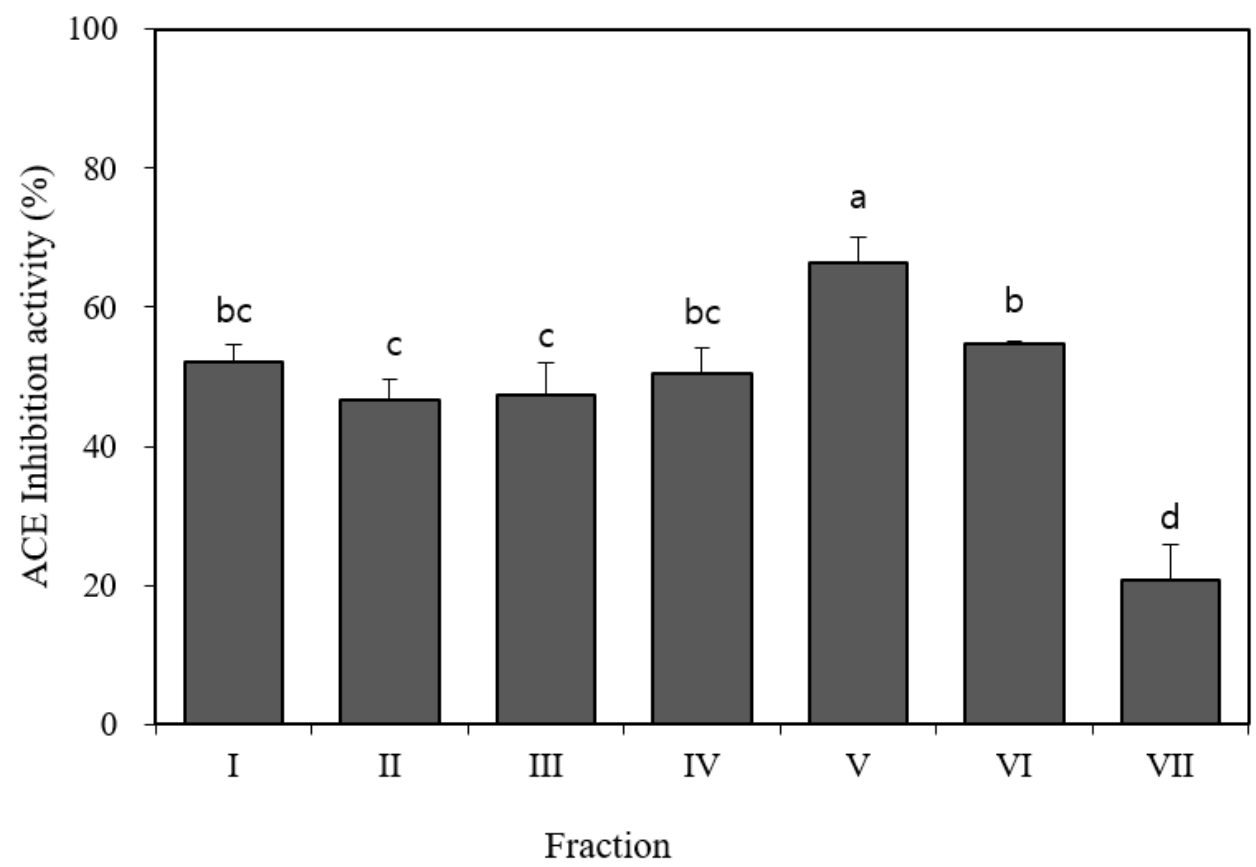

Figure 2. Angiotensin I-converting enzyme (ACE) inhibitory activity of seven different fractions separated from Hanwoo beef injected with thermolysin by P-2 gel filtration chromatography. Values are expressed as the means \pm standard deviation $(n=42)$. Error bars indicates SD. ${ }^{\text {a-d }}$ Different letters represent ACE inhibition activity that was significantly different $(p<0.05)$. 
of other studies that have identified four gel-filtrated ACE inhibitory fractions with an optimal molecular weight having smaller than $3 \mathrm{kDa}[12,14]$. The fraction $\mathrm{V}$ with the highest ACE inhibitory activity was selected for further separation by RP-HPLC.

The major peak fractions ( $\mathrm{V}-4,-5,-6,-7,-15,-\mathrm{m} 1$, and $-\mathrm{m} 2)$ were separated from fraction $\mathrm{V}$ by RP-HPLC. The most potent fractions (V-15, V-m1, and V-m2) that had the higher peptide concentrations and ACE inhibitory activities (Table 1) were selected and further analyzed by LC-MS/MS for sequencing.

\section{Isolated angiotensin I-converting enzyme inhibitory peptide sequencing}

The total mass of the peptide mixture in each fraction was obtained from the mass detector, and the monoisotopic mass of each individual amino acid was subtracted to identify the exact sequence with an accurate mass. The MS/MS spectra of the potent peptides were displayed using a single positively charged ion $\left(\mathrm{M}+[\mathrm{H}]^{+}\right)$and a total of twelve candidate peptides was identified from fraction V-15, V-m1, and V-m2 (Table 2). The highest ACE inhibitory activity was attributed to Leu-Ser-Trp $\left(\mathrm{IC}_{50}=0.89 \mathrm{mM}\right)$ from fraction $\mathrm{V}-15$. The quantitative analysis of the three peptides with the highest ACE inhibitory activity that was generated by thermolysin-injected beef loin followed by 3 days of aging at $5^{\circ} \mathrm{C}$-Leu-Ser-Trp, Phe-Gly-Tyr, and Tyr-Arg-Gln-was determined by LC-MS $(6.63,10.60$, and $29.91 \mathrm{ng} / \mathrm{kg}$ respectively). These peptides were not detected in the non-injected control sample (data not shown). Many studies have found ACE inhibitory peptides derived from red meat, poultry, and fish muscle using proteolytic enzymes or processing, including aging or fermentation $[6,15-$ 17]. Also, previous study showed that dry fermentation of sausage during ripening produced ACE inhibitory peptides through the proteolytic activity of endogenous proteinases combined with that of microbial enzymes $[18,19]$.

There are many reported protein structure-function studies that use different protein sources. Previous research has demon-

Table 1. Peptide concentration and angiotensin I-converting enzyme (ACE) inhibitory activity of RP-HPLC fractions at $1 \mathrm{mg} / \mathrm{mL}$ after gel filtration (fraction V)

\begin{tabular}{lcc}
\hline Fraction & Concentration $(\boldsymbol{\mu g} / \mathrm{mL})$ & ACE inhibitory activity $(\%)$ \\
\hline V-4 & $N D$ & $N D$ \\
V-5 & $N D$ & $N D$ \\
V-6 & $N D$ & $N D$ \\
V-7 & $N D$ & $N D$ \\
V-15 & $903.5 \pm 5.4^{\mathrm{b}}$ & $66.0 \pm 0.1^{\mathrm{b}}$ \\
V-m1 & $570.0 \pm 18.5^{\mathrm{c}}$ & $46.4 \pm 0.3^{\mathrm{c}}$ \\
V-m2 & $1,664.1 \pm 29.8^{\mathrm{a}}$ & $68.0 \pm 0.9^{\mathrm{a}}$ \\
\hline
\end{tabular}

RP-HPLC, reversed-phase high-performance liquid chromatography. Values are expressed as the means \pm standard deviation $(n=3)$. ND, not detected.

a-c Different letters within different fractions were significantly different $(p<0.05)$.
Table 2. The angiotensin I-converting enzyme (ACE) inhibitory activity (IC50) of chemically synthesized peptides

\begin{tabular}{llc}
\hline Source fraction & Peptide & IC $_{50}(\mathbf{m M})$ \\
\hline V-m1 & Tyr-Gly & 12.68 \\
& Tyr-Tyr & 8.60 \\
V-m2 & Tyr-Phe-Asn-Glu & 7.62 \\
V-15 & Val-Ser-Val & 9.08 \\
& Leu-Trp-Gly & 24.61 \\
& Phe-Gly-Tyr & 2.69 \\
& Val-Ser-Ser-Val & 8.49 \\
& Leu-Ser-Trp & 0.89 \\
& Met-Ala-Asp-Ala & 5.92 \\
& Tyr-Arg-Gln & 3.09 \\
& Gln-Pro-Ser-Gly-Ser-Gln & 8.78 \\
& Leu-Trp-His- His-Thr & 5.21 \\
\hline
\end{tabular}

$I_{50}$ value was defined as the concentration of inhibitor required to inhibit $50 \%$ of the ACE activity.

strated that ACE inhibitory peptides have some common characteristics: i) The C-terminal tripeptide sequence strongly affects binding to ACE even though the underlying mechanism has yet to be completely established [20]; ii) C-terminal hydrophobic amino acids can effectively bind to the ACE active site [21]; iii) Di- or tripeptides with aromatic or branched-chain amino acids at the N-terminus and Tyr, Phe, Trp, or Pro at the C-terminus have interactions with ACE active site amino acid residues due to their strong affinity towards the ACE active site [7,22-24]. In the present study, Leu-Ser-Trp, the peptide with the highest $\mathrm{ACE}$ inhibitory activity $\left(\mathrm{IC}_{50}=0.82 \mathrm{mM}\right)$ had an aromatic C-terminal Trp, corresponding with the results of another study [25]. Additionally, aromatic or branched-chain aliphatic amino acids including Leu, Ile, Ala, Trp, and Met, contribute to potent ACE inhibition, playing an important role in ACE binding $[7,25,26]$. The peptide Phe-Gly-Tyr that had an $\mathrm{IC}_{50}$ of $2.69 \mathrm{mM}$ for ACE inhibitory activity, consists of an aromatic amino acid at the $\mathrm{N}$-terminus and Tyr at the C-terminus. Tyr-Arg-Gln also consists of an aromatic amino acid at the $\mathrm{N}$-terminus. In other words, the three amino acidsequenced peptides (Leu-Ser-Trp, Phe-Gly-Tyr, and Tyr-ArgGln) derived from thermolysin-injected beef with the greatest potential for use as ACE inhibitory peptides have highly similar sequence properties with peptides with well-established ACE inhibitory activity $[27,28]$. From the present study, TyrGly exhibited lower ACE inhibitory activity in comparison with larger peptides (tri-, tetra-, penta-, or hexapeptides), except for Leu-Trp-Gly, despite their smaller size. This may be attributable to the absence of common ACE inhibitory peptide properties: C-terminal Tyr or hydrophobic amino acid or an $\mathrm{N}$-terminal aromatic or branched-chain amino acid. This indicates that both the length of the amino acid chain and its composition is important for bioactivity and bioavailability as a functional inhibitory peptide [29]. 


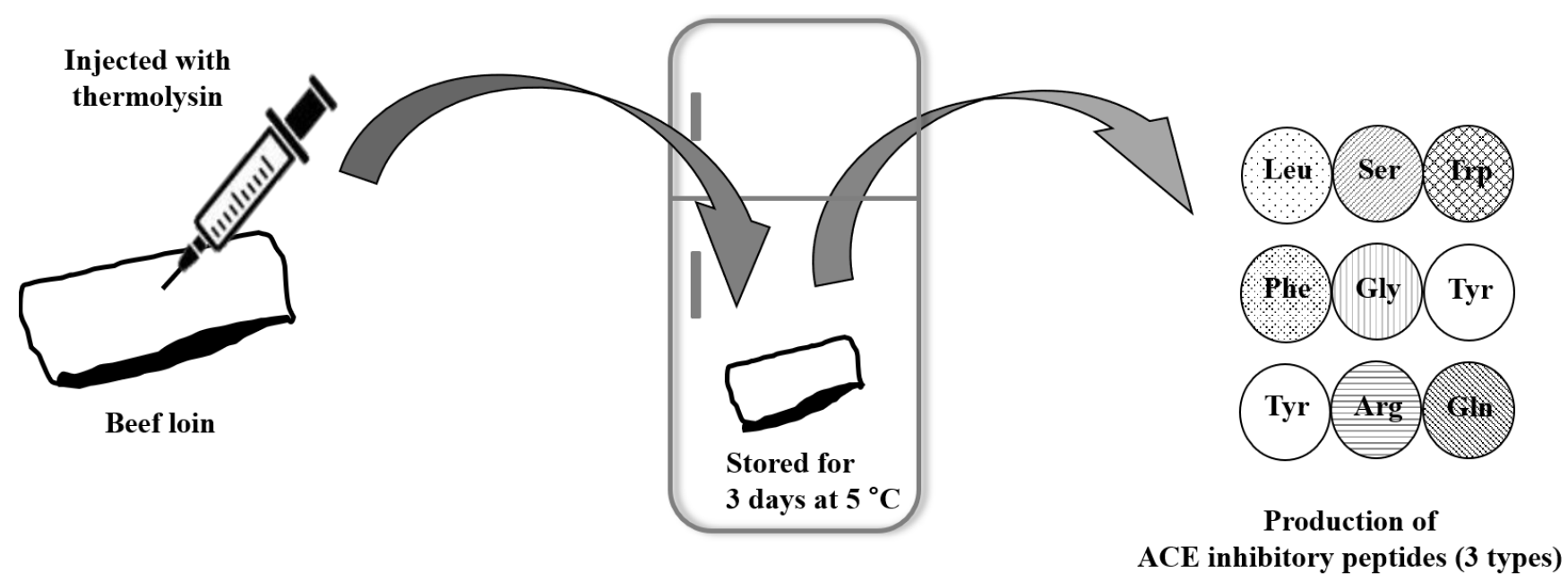

Figure 3. Schematic diagram of the production of angiotensin I-converting enzyme (ACE) inhibitory peptides from beef loin. Injection of thermolysin followed by 3 days refrigerated storage at $5^{\circ} \mathrm{C}$ increased $\mathrm{ACE}$ inhibitory activity of beef loin, which might be beneficial for human consumption.

Toopcham et al [7] reported that the tripeptide Met-CysSer, containing the branched-chain amino acid Met at the Nterminus, exhibited higher ACE inhibitory activity than that of tetrapeptide Ala-Leu-Ser-Cys. Jang et al [12] reported that the $\sim 3 \mathrm{kDa}$ peptide had the highest ACE inhibitory activity of the peptides derived from beef rump hydrolysates. Furthermore, containing only a few amino acid residues, these peptides are able to cross the digestive epithelial barrier and reach blood vessels, allowing them to reach peripheral organs and have beneficial effects for the organism [29]. Because small peptides are more easily absorbed in the intestinal tract than larger peptides [30] and peptides containing proline are generally resistant to enzymatic digestion [31], it is expected that the peptides produced from thermolysin-injected beef loin will have sufficient antihypertensive activities in vivo.

\section{CONCLUSION}

In the present study, strong ACE inhibitory peptides-LeuSer-Trp, Phe-Gly-Tyr, and Tyr-Arg-Gln-were produced and identified from thermolysin-injected beef. Based on results through ultrafiltration, gel filtration, RP-HPLC, and UPLCQTOF-MS/MS, injection of thermolysin into beef followed by 3 days refrigerated storage may increase ACE inhibition activity. Consequently, the consumption of the beef would be more beneficial for human health (Figure 3). Further research on ACE inhibition by the identified peptides in vivo will be a necessary step for their future use in the meat and meat products industry as functional biomaterials or a healthy dietetic method.

\section{CONFLICT OF INTEREST}

We certify that there is no conflict of interest with any financial organization regarding the material discussed in the manuscript.

\section{ACKNOWLEDGMENTS}

This study was supported by "High Value-added Food Technology Development Program (Project No. 316048-03)”, Korea Institute of Planning and Evaluation for Technology in Food, Agriculture, Forestry and Fisheries. Also, this work was supported by the BK21 Plus Program of the Department of Agricultural Biotechnology, Seoul National University, Seoul, Korea.

\section{REFERENCES}

1. Maruyama S. Angiotensin converting enzyme inhibitors. In: Kawagishi S, editor. Methods of study the nutraceuticals compounds in foods. Tokyo, Japan: Kakkaishutban Center; 1997. pp. 116-29.

2. Suzuki T, Ishikawa N, Meguro H. Angiotensin-I converting enzyme inhibiting activity in foods. Nippon Nogeikagaku Kaishi 1983;57:1143-7.

3. Barbui T, Masciull A, Ghirardi A, Carobbio A. ACE inhibitors and cytoreductive therapy in polycythemia vera. Blood 2017; 129:1226-7.

4. Adje E, Balti R, Kouach M, Guillochon D, Nedjar-Arroume N. a 67-106 of bovine hemoglobin: a new family of antimicrobial and angiotensin I-converting enzyme inhibitory peptides. Eur Food Res Technol 2011;232:637-46.

5. Seol KH, Choe J, Kim HJ, et al. Bioactivities of peptide fractions derived from proteolytic enzyme-injected Hanwoo longisimus muscle in a model system. Int J Food Prop 2018;21:220-7.

6. Mirdhayati I, Hermanianto J, Wijaya CH, Sajuthi D, Arihara, $\mathrm{K}$. Angiotensin converting enzyme (ACE) inhibitory and antihypertensive activities of protein hydrolysate from meat of 
Kacang goat (Capra aegagrus hircus). J Sci Food Agric 2016; 96:3536-42.

7. Toopcham T, Mes JJ, Wichers HJ, Roytrakul S, Yongsawatdigul J. Bioavailability of angiotensin I-converting enzyme (ACE) inhibitory peptides dericed from Virgibacillus halodenitrificans SK1-3-7 proteinases hydrolyzed tilapia muscle proteins. Food Chem 2017;220:190-7.

8. Pietrasik Z, Janz JAM. Influence of freezing and thawing on the hydration characteristics, quality, and consumer acceptance of whole muscle beef injected with solutions of salt and phosphate. Meat Sci 2009;83:523-32.

9. Pietrasik Z, Shand PJ. Effects of mechanical treatments and moisture enhancement on the processing characteristics and tenderness of beef semimembranosus roasts. Meat Sci 2005; 71:498-505.

10.Zhang B, Sun Q, Liu HJ, Li SZ, Jiang ZQ. Characterization of actinidin from Chinese kiwifruit cultivars and its applications in meat tenderization and production of angiotensin I-converting enzyme (ACE) inhibitory peptides. LWT Food Sci Technol 2017;78:1-7.

11. Seol KH, Song JH, Prayad T, et al. Assessment of the inhibitory activity of peptide extracts from Hanwoo musculus longissimus on angiotensin I-converting enzyme. Korean J Food Sci An 2011;31:663-7.

12. Jang A, Lee M. Purification and identification of angiotensin converting enzyme inhibitory peptides from beef hydrolysates. Meat Sci 2005;69:653-61.

13. Cushman DW, Cheung HS. Spectrophotometric assay and properties of the angiotensin-converting enzyme of rabbit lung. Biochem Pharmacol 1971;20:1637-48.

14. Jang A, Jo C, Kang KS, Lee M. Antimicrobial and human cancer cell cytotoxic effect of synthetic angiotensin-converting enzyme (ACE) inhibitory peptides. Food Chem 2008;107:327-36.

15. Fu Y, Young JF, Therkildsen M. Bioactive peptides in beef: Endogenous generation through postmortem aging. Meat Sci 2017; 123:134-42.

16. Gobba CD, Tompa G, Otte J. Bioactive peptides from caseins released by cold active proteolytic enzymes from Arsukibacterium ikkense. Food Chem 2014;165:205-15.

17.Liu D, Chen X, Huang J, Huang M, Zhou G. Generation of bioactive peptides from duck meat during post-mortem aging. Food Chem 2017;237:408-15.

18. Vaštag, Ž, Popovic L, Popovic S, Petrovic L, Pericin D. Antioxidant and angiotensin-I converting enzyme inhibitory activity in the water-soluble protein extract from Petrovac Sausage
(Petrovská Kolbása). Food Control 2010;21:1298-302.

19. Yim DG, Chung KY, Jo C, Nam KC. Use of alternative curing salts for processing salamis. Asian-Australas J Anim Sci 2018; 31:123-8.

20. Ryan JT, Ross RP, Bolton D, Fitzgerald GF, Stanton C. Bioactive peptides from muscle sources: meat and fish. Nutrients 2011; 3:765-91.

21. Mayer D, Naylor CB, Motoc I, Marshall GR. A unique geometry of the active site of angiotensin-converting enzyme consistent with structure-activity studies. J Comput Aided Mol Des 1987; 1:3-16.

22. Byun HG, Kim SK. Structure and activity of angiotensin I converting enzyme inhibitory peptides derived from Alaskan Pollack skin. J Biochem Mol Biol 2002;35:239-43.

23.Li GH, Le GW, Shi YH, Shrestha S. Angiotensin I-converting enzyme inhibitory peptides derived from food proteins and their physiological and pharmacological effects. Nutr Res 2004; 24:469-86.

24. Pan S, Wang S, Jing L, Yao D. Purification and characterization of a novel angiotensin-I converting enzyme (ACE)-inhibitory peptide derived from enzymatic hydrolysate of Enteromorpha clathrate protein. Food Chem 2016;211:423-30.

25. Cheung HS, Wang FL, Ondetti MA, Sabo EF, Cushman DW. Binding of peptide substrates and inhibitors of angiotensinconverting enzyme. Importance of the $\mathrm{COOH}$-terminal dipeptide sequence. J Biol Chem 1980;255:401-7.

26.Li GH, Wan J, Lee G, Shi Y. Novel angiotensin I-converting enzyme inhibitory peptides isolated from Alcalase hydrolysate of mung bean protein. J Pept Sci 2006;12:509-14.

27. Muruyama S, Mitachi H, Tanaka H, Tomizuka N, Suzuki, H. Studies on the active site and antihypertensive activity of angiotensin I-converting enzyme inhibitors derived from casein. Agric Biol Chem 1987;51:1581-6.

28.Lafarga T, Hayes M. Bioactive peptides from meat muscle and by-products: generation, functionality and application as functional ingredients. Meat Sci 2014;98:227-39.

29. Yust MM, Pedroche J, Giron-Calle J, et al. Production of ace inhibitory peptides by digestion of chickpea legumin with alcalase. Food Chem 2003;81:363-9.

30.Hara H, Funabiki R, Iwata M, Yamazaki K. Portal absorption of small peptides in rats under unrestrained conditions. J Nutr 1984;114:1122-9.

31.Kim.YS, Birtwhistle W, Kim YW. Peptide hydrolases in the brush border and soluble fractions of small intestinal mucosa of rat and man. J Clin Invest 1972;51:1419-30. 